\title{
PENERAPAN GROUP REALITY THERAPY BAGI WARGA BINAAN UNTUK MEMILIH KEGIATAN SETELAH KELUAR DARI RUANG PAMSUS LAPAS X
}

\author{
Jennyfer $^{1}$, Denrich Suryadi ${ }^{2}$, Indriyani Virginia ${ }^{3}$ \\ ${ }^{1}$ Jurusan Psikologi, Universitas Tarumanagara Jakarta \\ Email: jennyfer.michiyo@gmail.com \\ ${ }^{2}$ Jurusan Psikologi, Universitas Tarumanagara Jakarta \\ Email: angiedenrich@yahoo.com \\ ${ }^{3}$ Jurusan Psikologi, Universitas Tarumanagara Jakarta \\ Email: indriyani_virginia@yahoo.com
}

\begin{abstract}
ABSTRAK
Lapas X memiliki warga binaan sebanyak 3.110 orang. Jumlah tersebut melebihi batas maksimum yang dapat ditampung. Kurangnya sumber daya manusia dari lapas membuat tidak setiap warga binaan mendapatkan kesempatan untuk melakukan tes secara psikologis. Salah satu masalah yang dihadapi adalah banyak warga binaan yang belum mengetahui kegiatan apa yang akan diambil setelah keluar dari ruang pamsus. Oleh sebab itu, dibutuhkan terapi untuk membantu warga binaan memilih dengan tepat dan bijaksana kegiatan yang ada di Lapas $X$. Salah satu terapi yang dapat dilaksanakan adalah group Reality Therapy. Tujuan terapi kelompok ini adalah untuk mengarahkan serta membantu warga binaan untuk bertindak aktif dalam mencari dan memilih kegiatan setelah keluar dari ruang pamsus. Terapi ini mampu membantu individu dalam menemukan cara memenuhi kebutuhan-kebutuhannya secara adaptif. Model yang digunakan untuk menggambarkan keseluruhan prosesnya tetap sama yaitu WDEP. W adalah wants, $D$ adalah direction dan doing, E adalah evaluation, serta $P$ adalah Planing. Komponen-komponen WDEP adalah hal yang perlu dieksplorasi selama proses terapi. Hasil intervensi akan diukur dengan melihat skor pre-test dan post-test melalui pernyataan dan skala yang telah dibuat. Setelah intervensi, partisipan menunjukkan peningkatan skor. Peningkatan skor dilihat dari hasil pernyataan berdasarkan skala Likert, hal ini menunjukkan bahwa partisipan telah mampu memilih kegiatan di lapas dan mampu memahami materi yang dilihat dari isi catatan harian setiap akhir sesi. Selama intervensi berlangsung, partisipan mampu mengikuti intervensi dengan kooperatif dan aktif.
\end{abstract}

Kata kunci: Warga binaan, Group Reality Therapy, Lapas, Pemilihan kegiatan Lapas, Ruang pamsus.

\section{PENDAHULUAN \\ Latar Belakang}

Lembaga Pemasyarakatan (Lapas) X merupakan sebuah lembaga pemasyarakatan yang menampung, merawat, dan membina narapidana khususnya narkotika. Lapas mulai dioperasikan sejak tahun 2004, hingga saat ini Lapas X memiliki warga binaan sebanyak 3.110 orang, dengan kapasitas hunian 1.084 orang. Hal ini menunjukkan bahwa lapas mengalami overcrowded lebih dari $150 \%$ dari kapasitas yang seharusnya. Ruang pamsus (pengamanan khusus) cenderung berisikan 18-20 orang sedangkan ruangan itu sendiri seharusnya berisikan 3-4 orang. Akibatnya terjadi berbagai permasalahan terutama dalam lapas seperti kondisi lingkungan yang buruk sehingga memungkinkan untuk terjadinya resiko terserangnya penyakit, kurang ketersediaan kualitas air bersih, udara yang tidak berkualitas akibat kapasitas ruang yang cenderung kecil, serta ketidakmampuan warga binaan terutama di dalam ruang isolasi untuk mengikuti kegiatan (Humanda, Pranowowati, \& Siswanto, 2014). Warga binaan memiliki masalah yang berbeda. Hasilnya menunjukkan bahwa indeks tanggung jawab warga binaan lebih, pengendalian diri yang kurang, dan kesehatan menurun (Birashk, 2009). Salah satu permasalahan adalah ketika keluar dari ruang pamsus, warga binaan akan memilih kegiatan yang disediakan oleh Lapas X. 
Akan tetapi, terdapat warga binaan yang belum memilih kegiatan apa yang akan diambil setelah keluar dari ruang pamsus.

Menurut psikolog di Lapas X (wawancara, 15 April, 2017), kapasitas ruangan yang kurang memadai serta kondisi lingkungan memang menjadi salah satu kendala yang sering dikeluhkan oleh warga binaan di lapas. Hal tersebut terjadi dikarenakan jumlah warga binaan melebihi kapasitas. Keluhan ini umumnya disampaikan oleh warga binaan yang baru pindah dari rutan karena hal tersebut merupakan prosedur yang harus dijalankan oleh warga binaan untuk menjalani masa orientasi sehingga warga binaan harus tinggal di ruang pamsus selama kurang lebih sebulan. Banyaknya warga binaan juga membuat tidak semua warga binaan dapat memiliki kesempatan untuk melakukan tes secara psikologis seperti tes minat, bakat, dan kepribadian sebelum memilih kegiatan yang disediakan lapas. Kurangnya sumber daya manusia serta banyaknya warga binaan dari Lapas $\mathrm{X}$, membuat tes secara psikologis untuk membantu warga binaan memilih kegiatan yang tepat setelah keluar dari ruang pamsus tidak dapat dilakukan.

Pemeriksaan psikologis dilakukan kepada lima orang yang tinggal di ruang pamsus (YK, DJ, RMS, HL, dan AP). Dari hasil kuisioner tersebut ditemukan bahwa mereka akan segera keluar dari ruang pamsus namun mereka masih belum memilih kegiatan apa yang akan dipilih serta tidak mengetahui bagaimana cara untuk mendaftarkan diri dalam kegiatan tersebut. HL dan RMS mengatakan bahwa mereka akan mengikuti mayoritas pilihan teman-temannya. Kemudian, YK masih bingung karena tidak ada kegiatan yang membuatnya tertarik. DJ dan AP mengatakan bahwa mereka belum memilih pilihan kegiatan yang disediakan oleh Lapas X. Untuk memilih kegiatan yang tepat, setiap warga binaan harus diberikan tes secara psikologis seperti tes minat, bakat, dan kepribadian. Dengan begitu, warga binaan dapat memilih dengan bijak sesuai dengan hasil dari tes tersebut. Selain itu, akan diberikan intervensi untuk mengetahui kebutuhan dasar dari setiap warga binaan. YK, DJ, RMS, HL, dan AP mengatakan bahwa mereka belum pernah mengikuti tes minat dan bakat.

Tes minat yang digunakan adalah tes minat Holland. Tes Holland terdiri dari empat bagian, yang secara keseluruhannya untuk memperoleh gambaran mengenai bidang minat seseorang berdasarkan tipologi Guilford. Guilford membagi manusia dalam enam bidang interest dan sifat kepribadian yaitu mechanical, scientific, social welfare, clerical, business, dan aesthetic. Berdasarkan ke enam bidang interest tersebut Holland membuat analogi menjadi enam tipe kepribadian dan enam tipe lingkungan yang mempengaruhi pilihan atas bidang minat individu seperti tipe realistik, tipe investigatif, tipe artistik, tipe sosial, tipe enterprising, dan tipe conventional. Holland menggunakan pendekatan bahwa tingkah laku individu adalah merupakan hasil dari interaksi individu dengan lingkungannya, maka pandangan ke enam tipe kepribadian ini sejalan dengan tipe lingkungan yang akan ikut berinteraksi dan mempengaruhi pembentukan minat seseorang (dalam Santrock, 2001).

Dari pertimbangan data-data yang dimiliki, maka peneliti menilai bahwa kondisi lingkungan lapas dan banyaknya warga binaan saat ini membuat kurangnya binaan karena sumber daya manusia yang terbatas sehingga membuat beberapa warga binaan tidak terarah dan masih belum memilih kegiatan setelah keluar dari ruang pamsus. Dengan demikian, peneliti menilai bahwa diperlukan suatu cara agar warga binaan yang akan keluar dari ruang pamsus dapat memilih dengan bijak kegiatan yang disediakan oleh lapas sesuai dengan minat, bakat, dan kepribadian setiap warga binaaan. 
Salah satu cara membina dan mengarahkan warga binaan untuk memilih kegiatan dengan bijak adalah dengan cara memberikan tes minat dan bakat Holland serta disesuaikan dengan kepribadian setiap warga binaan dan intervensi yang akan diberikan group Reality Therapy yang bertujuan untuk mengarahkan serta membantu warga binaan untuk bertindak aktif dalam mencari dan memilih kegiatan setelah keluar dari ruang pamsus. Group Reality Therapy adalah metode konseling yang mengajarkan orang bagaimana cara mengatur hidup mereka sendiri, membuat pilihan yang lebih efektif, dan bagaimana mengembangkan kekuatan untuk mengatasi tekanan dan masalah kehidupan (Glasser, 2003). Group Reality Therapy adalah jalan bagi terapis untuk membantu klien memenuhi kebutuhan mereka sepenuhnya, memiliki perilaku yang lebih efektif dan untuk mencapai pertumbuhan dengan perilaku (Wabulding, 2004).

Group Reality Therapy telah terbukti menjadi strategi yang efektif dalam mencapai perubahan perilaku, penganiayaan anak, pemberontakan remaja, duka cita, hubungan orang tua, gangguan makan (Glasser, 1985), self-help (Good, 1987), kesehatan mental (Garner, 1983), program pemulihan (Reuss, 1985), self-esteem (Shea, 1973), dan kecanduan (Honeyman, 1990). Glasser (dikutip dalam Sharf, 2012) menekankan pentingnya action dan choice untuk mendeskripsikan perasaan-perasaan yang dialami individu. Menurut pandangan Glasser, perasaan muncul setelah sebuah situasi terjadi. Dalam hal ini, individu yang memilih untuk merasakan hal tersebut.

\section{Rumusan Masalah}

Apakah group Reality Therapy dapat mengarahkan warga binaan untuk memilih dengan tepat kegiatan yang disediakan oleh Lapas X sesuai dengan minat, bakat, dan kepribadian setiap warga binaan?

\section{Tujuan Penelitian}

Terapi kelompok bertujuan untuk mengarahkan warga binaan untuk memilih dengan tepat kegiatan yang disediakan oleh Lapas X sesuai dengan minat, bakat, dan kepribadian setiap warga binaan.

\section{METODE PENELITIAN}

\section{Partisipan Penelitian.}

Karakteristik partisipan yaitu: warga binaan di Lapas X, masih berada di ruang pamsus, warga binaan yang belum memilih kegiatan di lapas, usia 20-30 tahun, dan jenis kelamin pria.

\section{Desain Penelitian.}

Desain penelitian yang digunakan dalam penelitian ini adalah metode penelitian secara kualitatif melalui cognitive debriefing yaitu dengan dilakukan wawancara dengan kelompok warga binaan. Penelitian ini juga menggunakan pre-test dan post-test sebagai analisa untuk menentukan kriteria partisipan dan mengetahui perbandingan hasil sebelum dan sesudah pemberian intervensi.

\section{Lokasi Penelitian.}

Lokasi penelitian dilakukan di salah satu ruangan yag disediakan oleh Lapas X.

\section{Instrumen Penelitian.}

Peralatan yang digunakan adalah lembar informed consent, alat ukur Holland, kertas, pensil, catatan harian, dan laptop. 


\section{Pengukuran.}

Alat ukur yang digunakan adalah tes minat Holland untuk mengetahui minat warga binaan terhadap bidang tertentu. Alat ukur ini terdiri dari 214 item untuk mengukur tingkat minat di enam bidang interest dan sifat kepribadian. Setiap individu diminta untuk mengisi respon "suka" atau "tidak suka" pada setiap item. Alat ukur ini memiliki nilai reliabilitas 0,8 dan validitas 0,142 - 0.663. Hal ini menyatakan bahwa tes minat Holland valid dan reliable untuk mengetahui minat dan bakat dari warga binaan. Selain itu, peneliti juga menggunakan pernyataan sebagai pre-test dan post-test untuk mengetahui apakah warga binaan telah mengetahui minat pribadi masingmasing. Pernyataan berupa "Sebelum/sesudah mengikuti sesi seberapa jauh saya sudah mengetahui minat pribadi saya." Dengan skala Likert 1-5, dimana 1 adalah sangat tidak tahu sampai dengan 5 sangat tahu.

\section{Prosedur Penelitian.}

Dalam menentukan kesamaan kelompok menggunakan data yang diperoleh dari pihak lapas yaitu data mengenai warga binaan yang masih berada di ruang pamsus. Kemudian, peneliti memberikan kuesioner dan melakukan wawancara kepada setiap warga binaan untuk mencari warga binaan yang belum mengetahui kegiatan yang akan diambil setelah keluar dari ruang pamsus. Sebelum terapi dijalankan, dilakukan pre-test dengan mengisi pernyataan "Sebelum mengikuti sesi seberapa jauh saya sudah mengetahui minat pribadi saya." Dengan skala 1-5, dimana 1 adalah sangat tidak tahu sampai dengan 5 sangat tahu. Selanjutnya group Reality Therapy dilakukan. Setiap sesi, partisipan harus mengisi catatan harian yang bertujuan untuk mengetahui apakah setiap partisipan memahami setiap materi yang diberikan. Setelah itu, dilakukan post-test dengan mengisi pernyataan "Setelah mengikuti sesi seberapa jauh saya sudah mengetahui minat pribadi saya." Dengan skala 1-5, dimana 1 adalah sangat tidak tahu sampai dengan 5 sangat tahu.

\section{Pelaksanaan Penelitian.}

Metode yang digunakan adalah group Reality Therapy, model yang digunakan untuk menggambarkan keseluruhan prosesnya tetap sama, yaitu WDEP (Corey, 2012). Namun, model ini digunakan untuk mengatasi permasalahan setiap anggota secara umum dalam kelompok. Terdapat tiga tahap utama dalam group Reality Therapy, yaitu initial stage, working stage, dan final stage (Corey, 2012). Dalam initial stage, peneliti diharapkan dapat membangun suasana yang aman secara psikologis dalam kelompok, mendiskusikan informed consent, dan membuat aturan dan batasan. Selama proses transisi kelompok, peneliti akan menghadapi kecemasan, konflik, masalah pengendalian diri, serta sikap tertutup dari klien. Dalam working stage, peneliti perlu mendorong masing-masing anggota untuk memberikan tanggapan, mengevaluasi komitmen para anggota, membantu merumuskan masalah, dan mengajarkan cara mengatasi masalahnya. Menjelang final stage, peneliti merumuskan kembali masalah yang ada di dalam kelompok secara umum dan bersiap melakukan terminasi. Upaya yang dapat dilakukan di akhir terapi adalah menghadapi perasaan dan pikiran sebelum terapi selesai, menyelesaikan hal-hal yang belum terselesaikan, dan tetap belajar untuk menjadi pribadi yang lebih baik. Selain itu, peneliti perlu mengevaluasi program pada setiap anggota, mengkonstruksi gambaran untuk menyelesaikan masalah yang baru, dan merumuskan pandangan masing-masing anggota mengenai masa depan. Dengan demikian, Reality Therapy bertujuan untuk membantu individu dalam menemukan cara memenuhi kebutuhan-kebutuhannya secara adaptif (Corey, 2013). 


\section{HASIL INTERVENSI}

Pada sesi 1, intervensi dilaksanakan pada tanggal 18 Mei 2017 bertempat di ruang yang telah disediakan pihak lapas. Intervensi berjalan selama dua jam. peneliti memberikan lembar catatan harian kepada setiap partisipan guna untuk melihat sejauh mana partisipan memahami setiap sesi yang diberikan. Selain itu, peneliti meminta untuk memberikan tanda $X$ pada pernyataan "Sebelum mengikuti sesi seberapa jauh saya sudah mengetahui minat pribadi saya." Dengan skala 1-5, dimana 1 adalah sangat tidak tahu sampai dengan 5 sangat tahu. Setelah itu, peneliti menjelaskan proses terapi dari awal sampai akhir terlebih dahulu. Kemudian, peneliti memberikan psikoedukasi mengenai kegiatan yang disediakan oleh lapas. Tujuannya adalah agar para partisipan mengetahui kegiatan apa saja yang disediakan oleh lapas. Pemberian psikoedukasi mengenai kegiatan yang disediakan oleh lapas dalam bentuk visual yaitu berupa presentasi slide. Setelah peneliti menyelesaikan presentasi, peneliti meminta setiap partisipan untuk memilih dua kegiatan yang diinginkan. YK menjawab bahwa ia ingin mengikut band dan bahasa inggris, AP menjawab bahwa ia ingin mengikuti otomotif dan olahraga, RMS menjawab bahwa ia ingin menjadi tamping (pekerja) saja, HL menjawab ia hanya ingin mengikuti pesantren terpadu, dan DJ ingin mengikuti tataboga dan pesantren. Setelah menyebut pilihan kegiatan yang diinginkan, peneliti meminta partisipan untuk memberikan alasan mengapa memilih kegiatan tersebut.

YK menjawab bahwa ia ingin melanjutkan hobi bermain musik dan bahasa inggris untuk mengasah kemampuan dalam berbahasa karena setelah keluar dari Lapas, YK akan bekerja sebagai bartender di Bali, oleh karena itu YK harus belajar bahasa inggris untuk berkomunikasi dengan pelanggan. Kemudian, AP memilih otomotif karena menurut AP otomotif adalah hobi yang sangat maskulin dan AP memilih olahraga karena AP senang berolahraga terutama futsal. Setelah itu, RMS mengatakan bahwa RMS ingin menjadi tamping karena RMS malas untuk mengikuti kegiatan yang lain dan tujuan untuk menjadi tamping adalah mendapatkan uang serta dekat dengan petugas. RMS berharap pengurusan pembebasan bersyarat menjadi lebih mudah dengan menjadi tamping.

Kemudian HL hanya memilih pesantren karena HL mau mendekatkan diri ke Tuhan. Menurut HL, ia sudah lama tidak mendekatkan diri kepada Tuhan, oleh karena itu HL memilih untuk lebih fokus dalam religi. Setelah itu, DJ mengatakan ia ingin mengikuti tataboga karena ia memiliki dasar kemampuan dalam memasak. DJ pandai membuat makanan berat dan sambal tetapi ia ingin mencoba untuk masuk dalam dunia membuat kue atau roti. DJ berharap dengan masuk ke tataboga maka ia memiliki kemampuan membuat kue atau roti dan sekalian untuk mengisi waktu luang. DJ juga ingin mengikuti pesantren karena ia ingin mendekatkan diri ke Tuhan.

Setelah menyebutkan alasan, peneliti menampilkan slide yang berisi rekomendasi pilihan kegiatan yang sesuai dengan masing-masing partisipan berdasarkan tes psikologis yang telah dijalankan serta tes bakat dari Holland. 

UNTUK MEMILIH KEGIATAN SETELAH KELUAR DARI RUANG

Tabel 1. Rekomendasi Kegiatan

\begin{tabular}{ccccc}
\hline YK & AP & RMS & HL & DJ \\
\hline Pesantren & Pesantren & Gereja & Pesantren & Pesantren \\
\hline Criminon & Criminon & Criminon & Criminon & Criminon \\
\hline KDS & KDS & KDS & KDS & KDS \\
\hline Group band & Melukis & Group band & Komputer & Tataboga \\
\hline $\begin{array}{c}\text { Bahasa } \\
\text { Inggris }\end{array}$ & Perkebunan & Perikanan & Olahraga & Pramuka \\
\hline
\end{tabular}

Setelah itu, peneliti meminta partisipan merenungkan kembali kegiatan yang telah mereka pilih. peneliti meminta setiap partisipan untuk mengisi catatan harian yang telah diberikan. Setelah semua mengisi dan diberikan kembali kepada peneliti.

Sesi 2 dilaksanakan pada tanggal 22 Mei 2017. peneliti menanyakan kepada partisipan hal-hal apa saja yang diperlukan untuk memilih kegiatan yang diinginkan. Sesi 2 merupakan diskusi terbuka karena antar partisipan saling memberikan informasi yang diketahui untuk membantu partisipan lainnya. Selain itu, antar partisipan saling membahas apakah kegiatan yang diambil sesuai dengan pribadi masing-masing.

YK tetap memilih bahasa inggris dan group band sebagai kegiatan di lapas. Partisipan lain mengatakan bahwa YK memilih kegiatan bahasa inggris merupakan pilihan yang tepat. Selain membantu YK mengisi waktu luang, YK dapat menggunakannya ketika keluar dari lapas. Bahasa inggris juga merupakan bahasa yang berguna dan menambah nilai YK untuk mendapatkan pekerjaan sebagai bartender di Bali jika dapat menguasai bahasa inggris. Menurut partisipan lain, pilihan YK untuk mengikuti group band cukup baik karena ia bisa menyalurkan hobinya dalam musik.

AP memilih otomotif dan melukis sebagai kegiatan di lapas. Partisipan lain mengatakan bahwa pilihan kegiatan melukis sudah tepat untuk AP karena ia memiliki bakat menggambar dan melukis. Dinding pamsus sering menjadi wadah AP untuk menyalurkan hobinya. Tetapi, beberapa partisipan mengatakan bahwa otomotif kurang sesuai dengan AP karena jika AP marah dan tidak mengontrol perasaannya, maka AP dapat menggunakan perkakas sebagai senjata sehingga cukup membahayakan. AP mendengar dengan seksama masukan dari partisipan lain dan ia mengatakan bahwa ia akan merenungkannya terlebih dahulu.

RMS mengatakan bahwa ia ingin menjadi tamping. Peneliti mengatakan bahwa untuk menjadi tamping, RMS harus menjalankan dan mengikuti kegiatan terlebih dahulu. Kemudian RMS mengatakan bahwa jika harus mengikut kegiatan terlebih dahulu maka ia akan memilih group band karena ia memiliki teman dalam group band tersebut. RMS juga akan menyalurkan hobinya yang sudah lama tidak pernah ia lakukan. Partisipan lain mengatakan bahwa jika untuk menyalurkan hobi berarti pilihan RMS cukup tepat. Partisipan lain juga menyarankan RMS untuk menjadi tamping koperasi karena tamping koperasi dapat menghasilkan uang berupa gaji yang diberikan oleh perusahaan rekanan koperasi (pihak ketiga).

HL mengatakan bahwa ia menambahkan pilihan kegiatan yang diinginkan yaitu komputer. HL juga akan mengikuti pesantren jika waktu tidak bertabrakan. Partisipan yang lain mengatakan bahwa pilihan HL sudah tepat karena ia memiliki ilmu dasar dalam komputer karena HL bekerja 
di bidang teknisi laptop dan komputer. Jadi HL memiliki kemungkinan untuk bekerja di Lapas jika kemampuannya meningkat walaupun masih menjadi seorang warga binaan.

DJ mengatakan bahwa ia tetap pada pilihan pertama yaitu tataboga. Partisipan lain mengatakan bahwa DJ tidak pernah menunjukkan kemampuan dalam memasak. Akan tetapi, jika keluar dari ruang pamsus DJ harus membuktikan bahwa ia memang ahli dalam bidang tataboga. Partisipan lain menyarankan DJ untuk mengikuti kegiatan pramuka atau olahraga karena DJ jarang bergerak dan sering melamun. Setelah berdiskusi, peneliti meminta setiap partisipan untuk mengisi catatan harian.

Sesi 3 dilaksanakan pada tanggal 25 Mei 2017. Pada sesi 3, antar partisipan saling melakukan evaluasi mengenai kegiatan yang telah dipilih, bagaimana cara mengikuti/mendaftar kegiatan yang telah dipilih, selain itu antar partisipan saling memberikan feedback. Secara umum, partisipan telah mengetahui cara-cara dan syarat untuk masuk dalam kegiatan yang diminati. YK mengatakan bahwa untuk masuk dalam kegiatan bahasa inggris, ia cukup dengan mendaftarkan diri dan memenuhi syarat-syarat yang diberikan. Kemudian, AP mengatakan bahwa untuk kegiatan melukis dan otomotif memiliki cara yang sama dengan YK. HL juga berpendapat sama dengan YK. RMS menceritakan bahwa tidak perlu mengikuti kegiatan untuk menjadi tamping. Jika RMS memenuhi syarat maka ia bisa menjadi tamping. Sedangkan, DJ mengatakan bahwa ia memiliki teman yang mengurus di bagian tataboga sehingga kemungkinan ia masuk kebagian tataboga juga besar. Setelah berdiskusi, peneliti meminta setiap partisipan untuk mengisi catatan harian.

Sesi 4 dilaksanakan pada tanggal 29 Mei 2017. Pada sesi 4 dilakukan evalusi akhir, melakukan review terhadap hal yang telah diperoleh selama sesi terapi berlangsung, serta membuat perencanaan. peneliti meminta setiap partisipan membuat perencanaan setelah keluar dari ruang pamsus serta apa yang akan dilakukan setelah keluar dari lapas. Setiap partisipan telah memiliki rencana. YK mengatakan bahwa setelah keluar dari ruang pamsus ia akan mendaftarkan diri pada kegiatan bahasa inggris. Setelah keluar dari lapas, YK akan menerima tawaran kerja menjadi bartender di Bali dan membawa keluarganya tinggal di Bali. YK mengatakan bahwa ia berniat untuk berhenti mengedarkan narkoba dan mulai memperhatikan keluarga serta perkembangan anaknya. YK juga berharap bahwa dengan tidak terjun ke dunia narkoba maka ia tidak akan masuk ke lapas kembali karena bagi YK berada di Lapas membuang waktunya untuk produktif.

AP mengatakan bahwa setelah keluar dari ruang pamsus, ia mungkin akan melihat terlebih dahulu contoh kegiatan yang akan dilakukan setelah itu AP akan mendaftarkan diri pada kegiatan otomotif, melukis, dan perkebunan. AP juga mengatakan bahwa jika ia diterima semua maka ia akan lebih memprioritaskan otomotif karena menurut AP akan lebih berguna jika keluar dari lapas. Setelah keluar dari lapas, AP berharap ia dapat menjadi anak yang berbakti untuk ibu, karena selama berada di lapas, ibu merupakan orang yang paling mendukung AP. AP tidak ingin mengecewakan ibunya. AP berencana untuk membuka bengkel di sekitar tempat tinggalnya setelah keluar dari lapas.

RMS mengatakan bahwa ia sudah memiliki rencana untuk menjadi tamping. RMS akan mencari tahu lowongan tamping yang masih tersedia. Setelah keluar dari ruang pamsus maka RMS akan mencari orang yang dapat membantunya. Selain itu, RMS akan mendaftarkan diri di group band. RMS mengatakan bahwa ia masih belum mengetahui apa yang akan dilakukan setelah keluar 
dari lapas. Kemungkinan besar ia akan tinggal bersama kakaknya terlebih dahulu, setelah itu melihat peluang usaha yang baik.

Kemudian, HL mengatakan bahwa setelah keluar dari ruang pamsus maka ia akan mendaftarkan diri pada kelas komputer dan HL juga bertekat untuk aktif mengikuti pesantren. Setelah keluar dari lapas, HL akan kembali kepada keluarga dan mulai mencari pekerjaan. Pekerjaan yang sesuai dengannya yaitu kembali menjadi teknisi bidang elektronik. Selain hal tersebut menjadi pekerjaan tetap, HL menyatakan bahwa hal itu juga menjadi hobinya dari dulu.

Sedangkan, DJ mengatakan bahwa setelah keluar dari ruang pamsus, ia akan mencari teman yang bertugas di tataboga. DJ akan mendaftarkan diri dan meminta temannya untuk membantu mempermudah. DJ sudah memiliki rencana setelah keluar dari lapas. DJ akan kembali ke Lampung dan berencana untuk membuka rumah makan atau toko roti setelah itu DJ berencana untuk mencari pasangan hidup di Lampung.

Setelah membuat rencana dan melakukan evaluasi akhir. peneliti memberikan saran dan motivasi kepada setiap partisipan. peneliti meminta partisipan untuk mengisi catatan harian serta memberikan tanda $X$ pada pernyataan "Sesudah mengikuti sesi seberapa jauh saya mengetahui minat pribadi saya." Dengan skala 1-5, dimana 1 adalah sangat tidak tahu sampai dengan 5 sangat tahu. Setelah catatan harian dikembalikan ke peneliti. peneliti membagikan evaluasi kegiatan untuk diisi. Kemudian, peneliti melakukan terminasi dan mengakhiri sesi 4.

Tabel 2. Hasil Intervensi Seluruh Subyek

\begin{tabular}{ccc}
\hline Inisial & Pretest & Posttest \\
\hline AP & 3 & 5 \\
\hline RMS & 2 & 4 \\
\hline HL & 2 & 4 \\
\hline YK & 3 & 4 \\
\hline DJ & 2 & 5 \\
\hline
\end{tabular}

Dari tabel di atas, setiap partisipan mengalami kenaikan skor, sehingga dapat dikatakan bahwa intervensi berjalan dengan baik karena setiap partisipan sudah mampu memilih kegiatan setelah keluar dari ruang pamsus. Selain itu, partisipan juga memahami setiap materi dan sesi yang diberikan. Hal ini, dilihat dari catatan harian sesuai dengan materi yang dibahas setiap sesi.

\section{KESIMPULAN}

Berdasarkan dari group Reality Therapy yang telah dilaksanakan, dapat disimpulkan bahwa terdapat perubahan dari beberapa partisipan. Partisipan menjadi lebih sadar dan mengetahui kegiatan apa yang akan dipilih selama berada di lapas ini. Dari hasil wawancara dan observasi, partisipan telah mampu menentukan kegiatan yang benar-benar diinginkan oleh partisipan. Tujuan dari group Reality Therapy ini telah tercapai dengan baik. Tujuannya adalah membantu partisipan bahwa kondisi mereka saat ini merupakan konsekuensi dari perbuatan yang telah mereka lakukan. Selain itu, partisipan mulai menyadari minat, bakat, dan kepribadian mereka sehingga mereka dapat memilih dengan bijak kegiatan yang disediakan oleh lapas. Kemudian, dalam pembuatan rencana, secara keseluruhan, partisipan terlibat aktif dalam menceritakan keinginan mereka selama berada di lapas maupun setelah keluar dari lapas. YK memilih kegiatan 
bahasa inggris, AP memilih otomotif dan melukis, RMS memilih group band, HL memilih komputer, dan DJ memilih tataboga. Setelah keluar dari lapas, setiap partisipan memiliki rencana yang positif.

\section{Diskusi.}

Materi yang diberikan kepada kelompok telah sesuai dengan rancangan yang telah dibuat. Proses intervensi pun berjalan dengan sesuai rencana. Partisipan selalu hadir dan kooperatif. Selama sesi intervensi, intervensi dilakukan selama dua jam disesuaikan dengan diskusi kelompok yang dilakukan. Para partisipan mampu bekerja sama dan mengikuti aturan kelompok yang telah dibuat. Walaupun, beberapa kali partisipan memotong pembicaraan karena ingin menceritakan dan menjelaskan keinginan mereka. Dalam sesi diskusi, para partisipan terlibat aktif, mereka saling berdiskusi dengan baik dan telah sesuai dengan yang diharapkan. Para partisipan juga merasa terbantu karena menjelaskan dengan rinci kegiatan yang disediakan oleh lapas serta partisipan mengetahui minat, bakat, dan kepribadian masing-masing dengan menggunakan tes. Selama proses intervensi berlangsung, RMS dan AP merupakan partisipan yang paling aktif berbicara dan mengungkapkan pendapatnya sehingga beberapa kali mereka sempat memotong pembicaraan dari temannya. Namun, secara keseluruhan mereka mampu untuk menghargai dan bersemangat dalam berdiskusi. Kemudian, DJ dan YK kurang begitu aktif, namun mereka tetap terlibat dengan diskusi yang dilakukan. Sedangkan, HL merupakan partisipan yang paling moody karena terkadang ia aktif dan terkadang ia pasif tergantung suasana hatinya. Intervensi telah membantu partisipan dalam memilih kegiatan yang disediakan oleh lapas.

\section{Saran}

Partisipan direkomendasikan untuk membuat rencana serta melakukan kegiatan dan pekerjaan yang diinginkan serta yang mampu dilakukan selama berada di ruang pamsus. Rekomendasi ini diberikan agar partisipan dapat mengisi waktu luang selama berada di ruang pamsus sehingga tidak mengalami kebosanan dan kejenuhan. Selain itu, partisipan juga diharapkan mampu untuk memilih dengan bijak kegiatan yang telah disediakan oleh Lapas X. Dengan begitu, partisipan dapat mengikuti kegiatan sesuai dengan minat, bakat, dan kepribadian setiap partisipan serta dapat mengikuti program kegiatan dengan maksimal.

\section{REFERENSI}

Birashk, B. (2009). The role of prison on prisoner personality. Journal of improvement and education, 9:92-96.

Corey, G. (2012). Theory and practice of group counseling ( $8^{\text {th }}$ ed.). Belmont, CA: Cengage Learning.

Corey, G. (2013). Case approach to counseling and psychotherapy ( $8^{\text {th }}$ ed.). Belmont, CA: Brooks/Cole Cengage Learning.

Glasser, W. (1985). Control theory. New York, NY: HarperCollins.

Glasser, W. (2003). The Elihical Application of Choice Theory. Seminows, LLC: Home Study

Good, E. P. (1987). In pursuit of happiness. Chapel Hill, NC: New View Publications.

Honeyman, A. (1990). Perceptual changes in addicts as a consequence of reality therapy based on group treatment. Journal of Reality Therapy, 9:53-59.

Humanda, N., Pranowowati, P., Siswanto, Y. (2014). Analisis permasalahan kesehatan pada narapidana di lembaga pemasyarakatan klas IIA Ambarawa. Ambarawa: Stikes Ngundi Waluyo.

Santrock, J. W. (2001). Educational psychology ( $8^{\text {th }}$ ed.). New York, NY: McGraw-Hill. 
Sharf, R. S. (2012). Theories of psychotherapy and counseling: Concepts and cases. Belmont, CA: Cengage learning.

Shea, G. (1973). The effects of reality-therapy-oriented group counseling with delinquent, behavior-disordered students. Dissertation Abstracts International, 34: 4889-4890.

Wubolding, R.E. (2006) The Power of Belonging. International Journal of Reality Therapy, 55: 108-120. 